\title{
PHYSICAL ACTIVITY AND SYMPTOMS OF ANXIETY AND DEPRESSION AMONG MEDICAL STUDENTS DURING A PANDEMIC
}

Original Article ARTIGO ORIGINAL Artículo Original

\author{
ATIVIDADE FISICA ESINTOMASDEANSIEDADEEDEPRESSÃO ENTREESTUDANTES DEMEDICINA \\ DURANTEA PANDEMIA
}

\section{ACTIVIDADFÍSICA,SÍNTOMASDEANSIEDADYDEPRESIÓNENESTUDIANTESDEMEDICINADURANTELAPANDEMIA}

Tassia Barcelos Mendes ${ }^{1}$ (D)

(Graduation student in Medicine)

Karla Cardoso de Souza' (ID)

(Graduation student in Medicine)

Carolina Nunes França ${ }^{2}$ (iD)

(Physiotherapist)

Fabrício Eduardo Rossi ${ }^{3}$ (iD

(Physical Education Professional)

Rafael Pereira Guimarães Santos ${ }^{2}$ (DD (Physical Education Professional)

Kalil Duailibi (DD

(Physician)

Izabela Tuleta ${ }^{5}$ (ID

(Physician)

Jane de Eston Armond ${ }^{2}$ (ID

(Physician)

Brendon Stubbs ${ }^{6}$ (ID

(Physiotherapist)

Lucas Melo Neves',7 (iD

(Physical Education Professional)

1. Universidade de Santo Amaro, Sao Paulo, Brazil.

2. Universidade de Santo Amaro, Postgraduation Program in Health Sciences, Sao Paulo, Brazil.

3. Immunometabolism of Skeletal

Muscle and Exercise Research

Group, Department of Physical

Education and Professor at

Graduate Program in Science and

Health, Federal University of Piauí (UFPI), Teresina-PI, Brazil.

4. Universidade de Santo Amaro, Residency Specialty Coordinator in

Psychiatry, Sao Paulo, Brazil.

5. Muenster University Hospital,

Department of Cardiology I,

Muenster, Germany.

6. King's College London,

Department of Psychological

Medicine, Institute of Psychiatry,

Psychology and Neuroscience,

London, UK.

7. Faculdade de Medicina da Universidade de São Paulo, Bipolar Disorder Program (PROMAN), Department of Psychiatry, Sao Paulo, Brazil.

\section{Correspondence}

Lucas Melo Neves. Rua Prof. Enéas de Siqueira Neto, 340, Building F1, Health Sciences Room, Jardim das Imbuias, São Paulo, SP, Brazil. 04829-300.

lucasmeloneves@uol.com.br

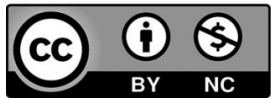

\section{ABSTRACT}

Introduction: Decreased physical activity has been associated with poorer mental health and is a cause for concern during the COVID-19 pandemic. Objective: To compare groups of medical students (MS) who practiced different levels of moderate and vigorous physical activity (MVPA) during the COVID-19 pandemic, in relation to symptoms of anxiety and depression (BAI-BDI), sleep quality (PSQI), and physical activity (PA) - light, moderate, vigorous (LPA-MPA and VPA), and sedentary behavior (SB). Methods: This research is a cross-sectional study involving $218 \mathrm{MS}$. Data on the characteristics of the MS were collected through online forms: PA, SB, BAI, BDI, and PSQI. The Cohen's D (Effect Size - ES) and confidence interval ( $95 \% \mathrm{Cl}$ ), Mann-Whitney test: Lower MVPA (Median=0 minute) and Higher MVPA (Median=390 minutes) were recorded. For the statistical analyses, we used: the Odds ratio (OR) for the presence of symptoms of high levels of anxiety and depression and poor sleep quality in the MS and MVPA. Results: We found a small ES for symptoms of depression (ES $0.2695 \% \mathrm{Cl} 0.00$ $0.53 p=0.029$ ), and significant differences ( $p<0.05$ ) for symptoms of anxiety ( $E S 0.1795 \% \mathrm{Cl}-0.090 .44 \mathrm{p}=0.037$ ). There was also a significant tendency for sedentary behavior on weekdays (ES $0.2795 \% \mathrm{Cl} 0.000 .53 p=0.051$ ). The OR for MVPA and the presence of symptoms of high levels of anxiety was $0.407(95 \% \mathrm{Cl}=0.228$ to 0.724$)$. Conclusions: the MS who practiced higher MVPA presented less symptoms of anxiety and depression during the COVID-19 pandemic. Level of evidence III; Case-control study.

Keywords: Sedentary behavior; University; Exercise; COVID-19; Coronavirus.

\section{RESUMO}

Introdução: A diminuição da atividade física tem sido associada à piora da saúde mental e é motivo de preocupação durante a pandemia de COVID-19. Objetivo: Comparar grupos de estudantes de medicina (EM) que praticam diferentes níveis de atividade física moderada e vigorosa (AFMV) durante a pandemia de COVID-19, com relação aos sintomas de ansiedade e depressão (BAI-BDI), qualidade do sono (PSQI), e atividade física (AF) - leve, moderada, vigorosa (AFL, AFM, AFV) e comportamento sedentário (CS). Métodos: Esta pesquisa com desenho transversal avaliou 218 EM. Os dados das características dos EM foram coletados por meio de formulários on-line: AF, CS, BAl, BDI e PSQI. Para as análises estatísticas, utilizou-se odds ratio (OR) para a presença de sintomas elevados de ansiedade e depressão e má qualidade do sono de EM e AFMV. O D de Cohen (tamanho do efeito, TE) e o intervalo de confiança (IC de 95\%), teste de Mann-Whitney: baix MVPA (mediana = 0 minuto) e alta MVPA (Mediana $=390$ minutos) foram registrados. Resultados: Encontramos um pequeno TE para sintomas de depressão (TE 0,26; IC de 95\%; 0,00-0,53; $p=0,029)$ e diferenças significativas $(p<0,05)$ para sintomas de ansiedade (TE 0,17; IC de 95\%; 0,09-0,44; $p=0,037)$. Também houve tendência de significância para o comportamento sedentário nos dias de semana (TE 0,27; IC de 95\%; 0,00-0,53; $p=0,051$ ). A OR para MVPA e a presença de sintomas de ansiedade elevada foi de 0,407 (IC de 95\% = 0,228-0,724). Conclusões: Os EM que praticavam maior MVPA apresentaram menos sintomas de ansiedade edepressão durante a pandemia de COVID-19. Nível de evidência III; Estudo de caso-controle.

Descritores: Comportamento sedentário; Universidades; Exercício físico; COVID-19; Coronavírus.

\section{RESUMEN}

Introducción: La disminución de la actividad física se ha asociado con un empeoramiento de la salud mentalyes motivo de preocupación durante la pandemia de COVID-19. Objetivo: Comparar grupos de estudiantes de medicina (EM) con diferentes momentos de actividad física moderada y vigorosa (AFMV) durante la pandemia COVID-19, en relación a los síntomas de ansiedad y depresión (BAI-BDI), calidad de sueño (PSQI) y actividad física (AF) - comportamiento leve, moderado, vigoroso (LPA-MPA y VPA) y sedentario (SB). Métodos: Esta encuesta transversal evaluó 218 $E M$. Los datos se recogieron mediante formularios online sobre las características del grupo PA, SB, BAI, BDI y PSQI. D de Cohen (ES) y el intervalo de confianza (IC del 95\%), prueba de Mann-Whitney: AFMV baja (mediana = 0 minutos) y 
AFMV (mediana = 390 minutos); En el análisis estadístico se utilizó la razón de probabilidades (OR) para la presencia de sintomas de ansiedad alta y sintomas depresivos, la mala calidad del sueño de la EM y la MVPA. Resultados: Una pequeña EE para síntomas de depresión (ES 0.26 IC 95\% 0.00 0.53 $p=0.029$ ) y diferencias significativas ( $p<0.05)$ para síntomas de ansiedad (ES 0.17 IC 95\% -0,09 0.44 p =0.037).Se verificó tendencia de significancia para el día de la semana SB (ES 0.27IC 95\% 0.00 0.53 $p=0.051$ ). Severificó la OR para AFMV y la presencia de síntomas de alta ansiedad de 0,407 (IC del 95\% = 0,228 a 0,724). Conclusiones: La EM con un AFMV más alto tiene menos sintomas de ansiedad y síntomas de depresión durante la pandemia de COVID-19. Nivel de evidencia III; Estudio de casos y controles.

\section{Descriptores: Conducta sedentaria; Universidades; Ejercicio físico; COVID-19; Coronavirus..}

\section{INTRODUCTION}

In December 2019, the coronavirus disease (COVID-19) emerged in Wuhan city and rapidly spread throughout China', and in January 2021, more than 90 million cases of the disease and 2 million deaths were registered worldwide. Until the creation and distribution of vaccines, non-pharmacological interventions are recommended by the World Health Organization (WHO) to decrease contamination, with actions such as: Physical distancing (e.g., spacing); Banning large public events (e.g., sports, arts and entertainment, and religion); Quarantine and isolation at home when the environment is safe; Safe workplaces, public transport and international travel (e.g., home-offices, public transports, bans, and quarantine, respectively). ${ }^{2}$

World wide data show that in March 2020, the recommendations of the WHO impacted approximately 1.5 billion students around the world (84\% of those matriculated) through closed schools, ${ }^{3}$ which resulted in the educational system being maintained by activities in the students' homes through online platforms during this period. In Brazil, this scenario occurred from March to December 2020, with no current prediction for a complete return. ${ }^{3}$

One important consequence of social isolation because of the COVID-19 pandemic is the decrease in physical activity by the general population. 4,5 Decreased physical activity has been associated with worsening mental health and is a cause for concern during the pandemic. ${ }^{6,7}$ In fact, the relation between physical activity and mental health has already been described, ${ }^{8-10}$ with convergent evidence indicating the use of physical activity in the primary prevention of different mental conditions, such as anxiety and depression. $.11,12$

Understanding the relationship between physical activity and the mental health of medical students (MS) during the COVID-19 pandemic is essential, mainly because before the pandemic, this group already presented changes in physical activity ${ }^{13,14}$ and mental health as high anxiety and depression symptoms and poor sleep quality. ${ }^{15-18}$ In fact, two crucial meta-analyses showed that established depression or at least depression symptoms affect $27.2 \%$ of MS worldwide ${ }^{18}$ and $51.5 \%$ of MS demonstrate poor sleep quality. ${ }^{17}$

Thus, the COVID-19 pandemic obliged Brazilian MS to perform their activities through online platforms for more than six months, decreasing physical activity. As a result, this population has a worse quality of mental health, which can be aggravated by less physical activity. Thus, we proposed to perform a cross-sectional study, identifying and comparing groups of MS with different times of moderate and vigorous physical activity (MVPA), about the anxiety and depression symptoms, sleep quality, and domains of physical activity - light physical activity (LPA), moderate physical activity (MPA), vigorous physical activity (VPA), and sedentary behavior (SB). We hypothesized that a worsening level of MVPA during the COVID-19 pandemic is related to higher scores on the scales of anxiety symptoms and depression symptoms, in addition to poor sleep quality in MS.

\section{MATERIAL AND METHODS}

\section{Study area and population}

Ethics and Research Committee approved this cross-sectional study (authorization number: 4.049.214) and followed the precepts of the Declaration of Helsinki. ${ }^{19}$ All MS agreed and signed the consent form. We developed the study between September 21 st and November 5th, 2020. During this period, 28,572 deaths from COVID-19 were recorded in Brazil and approximately 25,000 daily cases. ${ }^{20}$ Specifically, the Sao Paulo state, the epicenter of the pandemic in Brazil, up to January 15th, 2020, registered more than 1.6 million cases, 49,000 deaths due to COVID-19 complications (approximately $1 / 4$ of that registered in Brazil in the period) what results in values committed for health in pandemic around $\mathrm{R} \$ 5.26$ billion only in São Paulo state. ${ }^{20}$

All MS from the 1 st to the 12 th semester, regularly matriculated at the Santo Amaro University, of both sexes, $\geq 18$ years old, were invited to participate in the study. Contact was made via WhatsApp to present the proposal to evaluate the outcomes of interest (level of physical activity, SB, anxiety symptoms, depression symptoms, and quality of sleep). If the MS agreed to participate in the research, wed sent a link to the questionnaire (Google forms) containing the consent form and the questionnaires for the respective outcomes.

\section{Characteristics sample and self-perception during the $\mathrm{CO}$ - VID-19 pandemic}

We also included data regarding the characteristics of the sample on a questionnaire. We collected the following information: age, sex, semester of the course, the city lived before matriculating at medical school, the practice of physical exercise program, COVID-19 diagnosis, use of smoke and alcohol) and questions on the subject's self-perception regarding the worsening of their level of physical activity and SB, anxiety symptoms, depression symptoms, and quality of sleep during the COVID-19 pandemic. The sample size was determined using the Epitools epidemiological calculator ${ }^{21}$ available at (https://epitools.ausvet.com. $\mathrm{au} /$ ) and used data from previous studies on depression symptoms ${ }^{18}$ considering the accuracy of 0.05 , power of 0.9 , and a population of MS at the university evaluated of 1,000 MS, which indicated the necessity to evaluate at least $210 \mathrm{MS}$.

\section{Physical activity and sedentary behavior assessment}

We evaluated the level of physical activity by the International physical activity questionnaire (IPAQ), ${ }^{22}$ a tool widely used and validated for the Brazilian population. ${ }^{23}$ The questionnaire contains eight questions considering the routine of the previous seven days regarding physical activity and SB. We did a dichotomous division of the sample into two groups: Lower MVPA and Higher MVPA. The groups' Median and Interquartile (25 - 75) was: Lower MVPA $=0.0(0.0$ - 60.0) and Higher MVPA = 390 (265.0 - 540.0). We presented more details in the Results section. 


\section{Mood assessment}

We evaluated the mood through the validated instruments: Beck anxiety inventory (BAI) ${ }^{24}$ and Beck depressive inventory (BDI). ${ }^{25}$ Both questionnaires are composed of 21 multiple choice statements, each with four possible responses (0-3), and the final score ranges from 0 to 63 points.

The BAl is a widely used tool (26), validated for the Brazilian population. ${ }^{27}$ The cut-off point adopted to identify low and high anxiety symptoms followed that shown in a previous study: ${ }^{28}<13$ points (low anxiety symptoms) and $\geq 13$ points (high anxiety symptoms).

The BDI is also a commonly used tool, validated for the Brazilian population. ${ }^{29}$ The cut-off point adopted to identify low and high depression symptoms followed that shown in previous studies: ${ }^{30,31}<10$ points (low depression symptoms) and $\geq 10$ points (high depression symptoms).

\section{Sleep assessment}

The Pittsburgh Sleep Quality Index (PSQI) was used to analyze sleep quality. ${ }^{32}$ This tool is commonly used and was validated for the Brazilian population. ${ }^{33}$ The Pittsburgh scale contains questions regarding the sleep habits of the subject during the previous month (time to go to sleep, time to fall asleep, time to wake up, real hours of sleep, in addition to the frequency $(1,2$, or 3 times a week) of difficulty going to sleep in 30 minutes, waking up at night/dawn, getting up at night to go to the bathroom, difficulty breathing, coughing, snoring, cold, heat, bad dreams, other reasons). The final score ranges from 0 to 21 points. The most commonly reported cut-off point for MS in a recent meta-analysis was adopted: ${ }^{34}<6$ points (good sleep quality) and $\geq 6$ points (poor sleep quality).

\section{Statistical analysis}

We performed descriptive analysis, and we presented the characteristics of the participants in percentile and absolute values. The data were analyzed using IBM SPSS Statistics, version 22 (SPSS Inc., Chicago, IL, USA). First, we tested the data for normality using the Shapiro-Wilk test and the Levene test's equality of variances. For nonparametric data, we described variables as the median and interquartile range (25 - 75). Next, we performed to assess the differences between the groups the analyses using the nonparametric Mann-Whitney test. Next, we calculated the odds ratio (OR) for the presence of elevated anxiety symptoms, elevated depressive symptoms, and poor sleep quality of medical students who perform MVPA and the risk ratio prevalence for high anxiety symptoms, high depressive symptoms, and poor sleep quality of medical students who do not perform MVPA, with data presented as OR and $95 \%$ confidence intervals $(95 \% \mathrm{Cl})$. We used the Cohen's D Effect Size (ES) - 0 to $<0.30 \mid$ small, $|>0.30|$ to $\mid$ $<0.8 \mid$ medium, and $\mid>0.80$ | large (Cohen, 2013) - and confidence interval $(95 \% \mathrm{Cl})$ for determining the magnitude of difference and the precision of the estimate of the magnitude. Finally, we used the Spearman test to verify the correlations between anxiety symptoms, depression symptoms, sleep quality, SB on days of the week, SB on weekend days, LPA, MPA, and VPA. We considered a value of $p \leq 0.05$ as the limit of statistical significance.

\section{RESULTS}

The 12 semesters, totaling approximately 20 classes and 1,000 students, were contacted via WhatsApp message, in the respective class groups, by the class representatives. Thus, we included 218 MS $(21,8 \%)$ who answered the questionnaire. Table 1 presents the results regarding the characteristics of the sample.

The sample was predominantly composed of young people between 18 and 25 years (85.8\%), female (77.5\%), matriculated from the 1 st to the 4 th semester - basic cycle (53.6\%), and the majority (72.0\%) already lived in the city of São Paulo before enrolling on the medical course. A high percentage of MS did not realize $\geq 300$ minutes MVPA (68.3\%) and
Table 1. Characteristics of the participants.

\begin{tabular}{|c|c|c|c|}
\hline & Variable & $\%$ of MS & Total MS \\
\hline \multicolumn{4}{|c|}{ Age } \\
\hline & 18 to 25 years & 85.8 & 187 \\
\hline & 26 to 30 years & 9.6 & 21 \\
\hline & 31 to 35 years & 1.8 & 4 \\
\hline & 36 to 41 years & 2.8 & 6 \\
\hline \multicolumn{4}{|c|}{ Sex } \\
\hline & Female & 77.5 & 169 \\
\hline & Male & 22.5 & 49 \\
\hline \multicolumn{4}{|c|}{ Semester you are studying } \\
\hline 1 & \multirow{4}{*}{ Basic cycle (53.6\%) } & 11.7 & 26 \\
\hline 2 & & 6.0 & 13 \\
\hline 3 & & 26.6 & 58 \\
\hline 4 & & 8.3 & 18 \\
\hline 5 & \multirow{4}{*}{ Clinical cycle (41.4\%) } & 8.3 & 18 \\
\hline 6 & & 16.1 & 35 \\
\hline 7 & & 6.4 & 14 \\
\hline 8 & & 10.6 & 23 \\
\hline 9 & \multirow{3}{*}{ Boarding school (6.0\%) } & 3.7 & 8 \\
\hline 10 & & 1.8 & 4 \\
\hline 11 & & 0.5 & 1 \\
\hline
\end{tabular}

Did you live in this city before matriculating at medical school?

\begin{tabular}{c|c|c}
\hline Yes & 72.0 & 157 \\
\hline No & 28.0 & 61 \\
\hline Minutes of MVPA accumulated weekly? \\
\hline 0 to 299 minutes & 68.3 & 149 \\
\hline$\geq 300$ minutes & 31.7 & 69 \\
\hline \multicolumn{2}{c|}{ SB $\geq$ than 8 hours } \\
\hline Yes No & 82.1 & 179 \\
\hline No & 17.9 & 39 \\
\hline
\end{tabular}

Have you performed systematic physical exercises in the last six months? (This includes weight training, swimming, dancing, or any other type of activities, performed as part of your routine)

\begin{tabular}{|c|c|c|}
\hline Yes & 66.5 & 145 \\
\hline No & 33.5 & 73 \\
\hline \multicolumn{3}{|c|}{ Anxiety symptoms } \\
\hline 0 to 12 points (low anxiety symptoms *) & 49.5 & 108 \\
\hline$>12$ points (high anxiety symptoms *) & 50.5 & 110 \\
\hline \multicolumn{3}{|c|}{ Depression symptoms } \\
\hline 0 to 10 points (low depression symptoms ${ }^{* *}$ ) & 49.5 & 108 \\
\hline$>10$ points (elevated depression symptoms ${ }^{* *}$ ) & 50.5 & 110 \\
\hline \multicolumn{3}{|l|}{ Sleep quality } \\
\hline Good sleep quality & 34.9 & 76 \\
\hline Poor sleep quality & 65.1 & 142 \\
\hline \multicolumn{3}{|c|}{ Have you had a COVID-19 diagnosis? } \\
\hline Yes & 9.2 & 20 \\
\hline No & 90.8 & 198 \\
\hline
\end{tabular}

Do you consider that the COVID-19 pandemic changed your level of physical activity and SB?

\begin{tabular}{c|c|c}
\hline Yes & 83.5 & 182 \\
\hline No & 16.5 & 36 \\
\hline $\begin{array}{c}\text { Do you consider that the COVID-19 pandemic } \\
\text { changed your level of anxiety symptoms? }\end{array}$ \\
\hline Yes & 82.2 & 179 \\
\hline No & 17.8 & 39 \\
\hline
\end{tabular}

Do you consider that the COVID-19 pandemic changed your level of depression symptoms?

\begin{tabular}{c|c|c}
\hline Yes & 54.6 & 119 \\
\hline No Do you use cigarettes? & 45.4 & 99 \\
\hline \multicolumn{1}{|c|}{ Yes } & 16.1 & 35 \\
\hline No Do you use alcohol? \\
\hline Yes & 83.9 & 183 \\
\hline No & 66.1 & 144 \\
\hline
\end{tabular}

$\mathrm{SB}=$ sedentary behavior; MVPA = moderate and vigorous physical activity; ${ }^{*}$ Based on a cut-off of SFMUNDSSON et al. (2011). **Based on cut-off of Gomes et al., (2012). 
did more than 8 hours a day of sedentary behavior (82.1\%). In addition, 9.2\% of MS reported COVID-19 diagnosis.

Table 2 presents the odds ratios for the presence of elevated anxiety symptoms, elevated depressive symptoms, and poor sleep quality of medical students who perform MVPA and the risk ratio prevalence for high anxiety symptoms, high depressive symptoms, and poor sleep quality of medical students who do not perform MVPA.

The odds ratio to MVPA and elevated anxiety symptoms was 0.407 $(95 \% \mathrm{Cl}=0.228$ to 0.724$)$.

Figure 1 shows the comparisons between the two groups, dichotomized into lower MVPA group and higher MVPA group for BAI, BDI, and PSQI.

The comparisons between Lower MVPA and Higher MVPA indicate statistically significant differences for anxiety symptoms, small ES and statistically significant differences for depression symptoms, and no differences for sleep quality.

Table 2. Odds ratios for the presence of elevated anxiety symptoms, elevated depressive symptoms, and poor sleep quality of medical students who perform MVPA and risk ratio prevalence for high anxiety symptoms, high depressive symptoms, and poor sleep quality of medical students who do not perform MVPA.

\begin{tabular}{c|c|c|c|c|c}
\hline \multicolumn{3}{c|}{ Odds ratio } & \multicolumn{2}{c}{ Risk ratio prevalence } \\
\hline Variables & Value & $\begin{array}{c}95 \% \text { confidence } \\
\text { interval }\end{array}$ & Variables & $\%$ \\
\hline $\begin{array}{c}\text { Perform MVPA and } \\
\text { presence of elevated } \\
\text { anxiety symptoms }\end{array}$ & $0.407^{*}$ & 0.228 & 0.724 & $\begin{array}{c}\text { Not perform MVPA and } \\
\text { presence of elevated } \\
\text { anxiety symptoms }\end{array}$ & $64 \%$ \\
\hline $\begin{array}{c}\text { Perform MVPA and } \\
\text { presence of elevated } \\
\text { depression symptoms }\end{array}$ & 0.673 & 0.384 & 1.182 & $\begin{array}{c}\text { Not perform MVPA } \\
\text { and presence of high } \\
\text { depressive symptoms }\end{array}$ & $56 \%$ \\
\hline $\begin{array}{c}\text { Perform MVPA and } \\
\text { presence of poor } \\
\text { sleep quality }\end{array}$ & 0.652 & 0.365 & 1.163 & $\begin{array}{c}\text { Not perform MVPA } \\
\text { and presence of } \\
\text { poor sleep quality }\end{array}$ & $59 \%$ \\
\hline $\begin{array}{l}\text { MVPA = moderate and vigorous physical activity; }{ }^{*}=\text { confidence interval without crossing 1.0 (difference with } \\
\text { statistical significance). }\end{array}$
\end{tabular}

Table 3 presents the comparisons between the two groups, dichotomized into lower MVPA group and higher MVPA group for IPAQ outcomes.

We verified for moderate to large ES and statistically significant differences for the variable's physical activity: light PA, moderate PA, and vigorous PA. In addition, we verified a moderate ES and tendency of statistically significant differences for weekday SB and a large ES and statistically significant differences for the variable MVPA. We did not verify differences for sleep quality, SB on weekend days and SB on days of the week.

Table 4 shows the correlation between different physical activity levels, SB on days of the week, and SB weekend days for anxiety symptoms, depression symptoms, and sleep quality.

We verified correlation with statistically significant differences between Anxiety Symptoms and VPA or MVPA; Depression Symptoms and MPA or VPA or MVPA. SB weekend days (hours per day) and VPA or MVPA.

Table 5 presents an exploratory analysis with comparisons between dichotomized groups considering: Sex (female and male), Alcohol use (Yes or No), COVID-19 diagnosis (Yes or No), Changes in the level of PA or SB due to the COVID-19 pandemic (Yes or No), Anxiety symptoms $>12$ points (Yes or No), Depression symptoms >10 points (Yes or No), Performing systematic physical exercises in the last six months (Yes or No into lower MVPA group and score of MVPA, Sleep quality, Anxiety symptoms, and Depression symptoms.

Table 4. Correlation between physical activity levels, and SB on all days of the week, SB weekday anxiety symptoms, depression symptoms, sleep quality.

\begin{tabular}{c|c|c|c|c}
\hline & LPA & MPA & VPA & MVPA \\
\hline Anxiety Symptoms & -0.002 & -0.075 & $-0.251^{*}$ & $-0.167^{* *}$ \\
\hline Depression Symptoms & -0.096 & $-0.153^{* *}$ & $-0.193^{* *}$ & $-0.161^{* *}$ \\
\hline Sleep quality & -0.016 & -0.094 & -0.088 & -0.081 \\
\hline SB days of week (hours per day) & -0.039 & -0.067 & -0.090 & -0.124 \\
\hline SB weekend days (hours per day) & -0.014 & -0.099 & $-0.146^{* *}$ & $-0.169^{* *}$ \\
\hline
\end{tabular}

$\mathrm{LPA}=$ light physical activity; $\mathrm{MPA}=$ moderate physical activity; $\mathrm{VPA}=$ vigorous physical activity; $\mathrm{MVPA}=$ moderate and vigorous physical activity; ${ }^{*}=<0.0001 ;{ }^{* *}=\mathrm{p}<0.05 ; \mathrm{SB}=$ sedentary behavior.

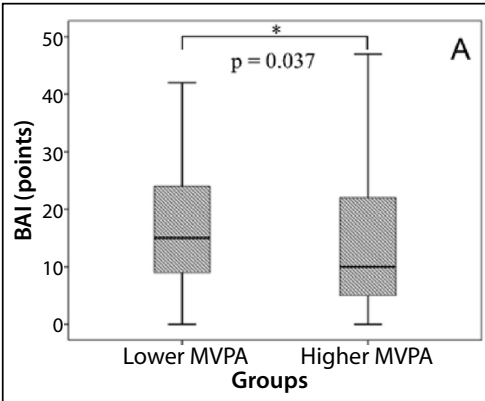

* difference with statistical significance $p<0$
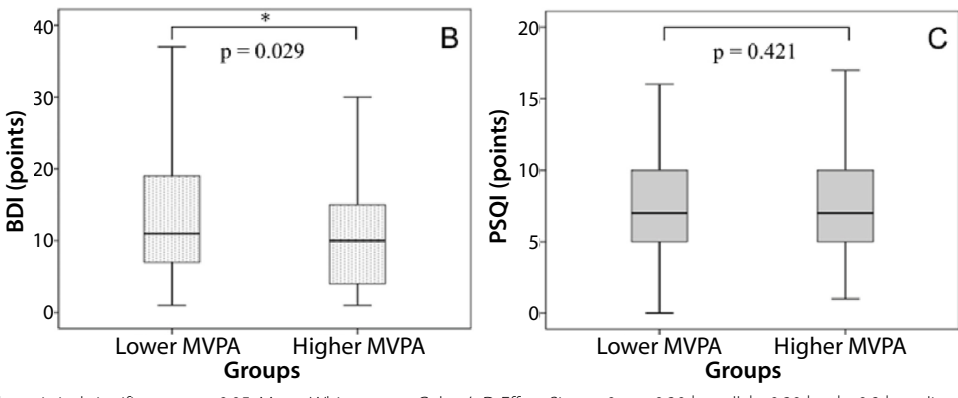

\section{Cohen's D \\ Effect size $95 \% \mathrm{Cl}$ (Lower upper) \\ $\operatorname{BAI}(A)=0.17(-0.090 .44)$ \\ $\mathrm{BDI}(\mathrm{B})=0.26(0.000 .53)$ \\ PSQI $(C)=0.06(-0.200 .33)$}

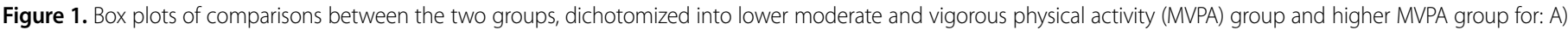
Beck anxiety inventory (BAI); B) Beck depression inventory (BDI); and C) Pittsburgh Sleep Quality Index (PSQI).

Table 3. Comparisons between the two groups, dichotomized into Lower MVPA and Higher MVPA for IPAQ outcomes.

\begin{tabular}{|c|c|c|c|c|c|c|}
\hline \multirow[b]{2}{*}{ Variable } & \multicolumn{2}{|c|}{$\begin{array}{l}\text { Lower MVPA } \\
\quad(n=109)\end{array}$} & \multicolumn{2}{|c|}{$\begin{array}{l}\text { Higher MVPA } \\
\quad(n=109)\end{array}$} & \multirow[b]{2}{*}{$\begin{array}{c}\text { Cohen's D - Effect } \\
\text { Size for T-Test } \\
\text { 95\% Cl (Lower Upper) }\end{array}$} & \multirow[b]{2}{*}{$\begin{array}{c}\text { Mann-Whitney } \\
\text { Test }\end{array}$} \\
\hline & $\begin{array}{c}\text { Median } \\
\text { Interquartile } \\
(25-75)\end{array}$ & $\begin{array}{l}\text { Minimum } \\
\text { maximum }\end{array}$ & $\begin{array}{c}\text { Median } \\
\text { Interquartile } \\
(25-75)\end{array}$ & $\begin{array}{l}\text { Minimum } \\
\text { maximum }\end{array}$ & & \\
\hline IPAQ - LPA (minutes per week) & $40.0(0.0-120.0)$ & $0.0-540.0$ & $120.0(5.0-270.0)$ & $0.0-900.0$ & $-0.52(-0.79-0.25)$ & $p<0.001$ \\
\hline IPAQ - MPA (minutes per week) & $0.0(0.0-60.0)$ & $0.0-300.0$ & $200.0(120.0-360.0)$ & $0.0-1200.0$ & $-1.54(-1.81-1.27)$ & $p<0.001$ \\
\hline IPAQ - VPA (minutes per week) & $0.0(0.0-0.0)$ & $0.0-240.0$ & $180(40.0-270.0)$ & $0.0-1080.0$ & $-1.38(-1.64-1.11)$ & $p<0.001$ \\
\hline IPAQ - MVPA (minutes per week) & $0.0(0.0-60.0)$ & $0.0-160.0$ & $390(265.0-540.0)$ & $170.0-1470.0$ & $-2.15(-2.42-1.88)$ & $p<0.001$ \\
\hline IPAQ - SB weekday (hours per day) & $10.0(8.5-14.0)$ & $2.0-18.0$ & $10.0(8.0-12.0)$ & $3-16.0$ & $0.27(0.000 .53)$ & $p=0.051$ \\
\hline IPAQ - SB weekend days (hours per day) & $9.0(6.0-12.0)$ & $3.0-16.0$ & $8.0(6.0-10.5)$ & $2-16.0$ & $0.10(-0.170 .37)$ & n.s. $p=0.473$ \\
\hline IPAQ - SB on days of week (hours per day) & $10.0(8.1-12.6)$ & $4.3-17.4$ & $9.6(7.6-11.8)$ & $3.4-16.0$ & $0.24(-0.030 .51)$ & n.s. $p=0.095$ \\
\hline
\end{tabular}

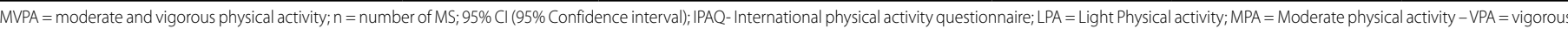
physical activity; $\mathrm{MVPA}=$ Moderate and vigorous physical activity; $\mathrm{PA}=$ Physical activity; SB = Sedentary behavior. 


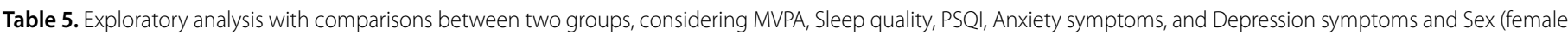

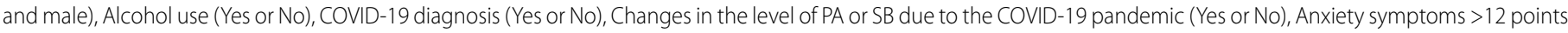

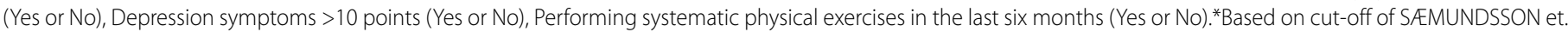
al., (2011). ${ }^{* *}$ Based on a cut-off of Gomes et al. (2012).

\begin{tabular}{|c|c|c|c|c|c|}
\hline Variable & Groups & $\begin{array}{c}\text { Median } \\
\text { Interquartile }(25-75)\end{array}$ & $\begin{array}{c}\text { Mann-Whitney } \\
\text { Test }\end{array}$ & $\begin{array}{c}\text { Median } \\
\text { Interquartile }(25-75) \\
\end{array}$ & Mann-Whitney Test \\
\hline & \multicolumn{3}{|c|}{ MVPA - IPAQ } & \multicolumn{2}{|c|}{ Sleep quality - PSQI } \\
\hline \multirow{2}{*}{ Sex } & Female $(n=169)$ & $160.0(0.0-375.0)$ & \multirow{2}{*}{$p=0.082$} & $7.0(5.0-10.0)$ & \multirow{2}{*}{$p=0.854$} \\
\hline & Male $(n=49)$ & $200.0(0.0-435.0)$ & & $6.0(4.0-9.0)$ & \\
\hline \multirow{2}{*}{ Have you had a COVID-19 diagnosis? } & Yes $(n=20)$ & $250.0(0.0-472.5)$ & \multirow{2}{*}{$p=0.281$} & $8.0(5.0-11.5)$ & \multirow{2}{*}{$p=0.594$} \\
\hline & No $(n=198)$ & $160.0(0.0-360.0)$ & & $7.0(5.0-10.0)$ & \\
\hline \multirow{2}{*}{$\begin{array}{c}\text { COVID-19 pandemic changed } \\
\text { your level of PA or SB? }\end{array}$} & Yes $(n=182)$ & $120.0(0.0-360.0)$ & \multirow{2}{*}{$p=0.121$} & $7.0(5.0-9.0)$ & \multirow{2}{*}{$p=0.004$} \\
\hline & No $(n=36)$ & $300.0(135.0-525.0)$ & & $7.0(5.0-13.0)$ & \\
\hline \multirow{2}{*}{ Anxiety symptoms $>12$ points } & Yes $(n=110)$ & $90.0(0.0-285.0)$ & \multirow{2}{*}{$p=0.005$} & $8.0(6.0-12.0)$ & \multirow{2}{*}{$p=0.038$} \\
\hline & No $(n=108)$ & $240.0(60.0-450.0)$ & & $5.0(4.0-8.0)$ & \\
\hline \multirow{2}{*}{ Depression symptoms $>10$ points } & Yes $(n=110)$ & $120.0(0.0-332.5)$ & \multirow{2}{*}{$p<0.0001$} & $9.0(6.0-12.0)$ & \multirow{2}{*}{$P=0.003$} \\
\hline & No $(n=108)$ & $205.0(32.5-442.5)$ & & $5.0(4.0-7.5)$ & \\
\hline \multirow{2}{*}{$\begin{array}{l}\text { Perform physical exercises } \\
\text { in the last } 6 \text { months }\end{array}$} & Yes $(n=145)$ & $300.0(120.0-495.0)$ & \multirow{2}{*}{$p=0.569$} & $7.0(4.8-10.0)$ & \multirow{2}{*}{$p<0.0001$} \\
\hline & No $(n=73)$ & $0.0(0.0-60.0)$ & & $7.0(5.0-9.0)$ & \\
\hline & \multicolumn{3}{|c|}{ Anxiety symptoms - BAI } & \multicolumn{2}{|c|}{ Depression symptoms - BDI } \\
\hline \multirow{2}{*}{ Sex } & Female $(n=169)$ & $14.00(7.00-25.00)$ & \multirow{2}{*}{$p<0.0001$} & $11.0(6.0-18.0)$ & \multirow{2}{*}{$p=0.101$} \\
\hline & Male $(n=49)$ & $9.00(2.00-17.00)$ & & $9.0(3.0-18.0)$ & \\
\hline \multirow{2}{*}{ Have you had a COVID-19 diagnosis? } & Yes $(n=20)$ & $12.50(8.50-29.50)$ & \multirow{2}{*}{$p=0.312$} & $13.5(6.0-23.8)$ & \multirow{2}{*}{$p=0.113$} \\
\hline & No $(n=198)$ & $13.00(5.00-24.00)$ & & $10.0(5.0-17.0)$ & \\
\hline \multirow{2}{*}{$\begin{array}{c}\text { COVID-19 pandemic changed } \\
\text { your level of PA or SB? }\end{array}$} & Yes $(n=182)$ & $12.50(5.00-23.25)$ & \multirow{2}{*}{$p=0.288$} & $11.0(6.0-16.3)$ & \multirow{2}{*}{$p=0.997$} \\
\hline & No $(n=36)$ & $15.50(5.25-27.50)$ & & $8.5(4.0-24.8)$ & \\
\hline \multirow{2}{*}{ Anxiety symptoms >10 points* } & Yes $(n=110)$ & - & \multirow{2}{*}{--} & $15.0(10.0-23.0)$ & \\
\hline & No $(n=108)$ & - & & $6.0(3.0-11.0)$ & 0.0001 \\
\hline $\mathrm{D}$ & Yes $(n=110)$ & $21.00(11.75-30.00)$ & & - & \\
\hline Depression symptoms > Iu poInts & No $(n=108)$ & $6.00(3.00-14.00)$ & $p<0.0001$ & - & -- \\
\hline Perform physical exercises & Yes $(n=145)$ & $10.00(5.00-21.50)$ & & $10.0(4.0-15.5)$ & \\
\hline in the last 6 months & No $(n=73)$ & $16.00(9.00-26.00)$ & $0<0.0001$ & $11.0(7.0-22.0)$ & 0.0 \\
\hline
\end{tabular}

\section{DISCUSSION}

The objective of this study was to compare groups of MS during the COVID-19 pandemic with different times of MVPA about domains of anxiety and depression symptoms, sleep quality, and physical activity - light, moderate, vigorous, and sedentary behavior. To our knowledge, this is the first study with a Brazilian sample, and MS with higher MVPA present lower anxiety symptoms and depression symptoms during the COVID-19 pandemic.

Higher time of MVPA was related to decreased anxiety symptoms and depression symptoms in clinical populations ${ }^{10,11}$ and in $\mathrm{MS}^{17}$ which supports our findings. Interestingly, in MS, the main barriers to physical activity are studying and working in extra periods, ${ }^{13}$ which could have worsened in the pandemic period, mainly because during the COVID-19 pandemic, the online activities for MS represent a challenge related to time management. ${ }^{35}$ Information on the MS participants before the pandemic to compare changes in MVPA or anxiety symptoms and depression symptoms would allow better analysis. However, data of Italian MS showed decreased MVPA during the COVID-19 pandemic compared to a period outside the pandemic (approximately 50\%) and an increase in SB (approximately 20\%) ) $^{36}$ which also supports our findings.

We verified moderate and large ES and statistically significant differences in physical activity (LPA, MPA, VPA). Although we expected the differences for MPA and VPA as the group was dichotomized by the MVPA variable (MVPA = MPA + VPA), the difference for $L P A$ is an important finding. Higher LPA may reflect lower SB, which is a behavior targeted for change and represents a big challenge for the area of sports medicine. Although we did not observe an ES and statistically significant difference for all SB measurements, small ES and a tendency to statistically significant difference were observed for SB on weekdays. SB has been associated with worse mental health in different clinical groups, ${ }^{10}$ and specifically during the COVID-19 pandemic, studies have already verified this relationship in other samples of the population, ${ }^{5}$ as well as greater SB in medical students, as already highlighted. ${ }^{36}$

It is essential to highlight that in our results, $68.3 \%$ did not perform 300 minutes of MVPA per week, and $82.1 \%$ remained in SB for more than 8 hours a day, even though $66.5 \%$ of MS reported that they had performed systematic physical exercise practices in the previous six months. This situation could have been influenced by the location for performance of systematic physical exercise (e.g., gym), which also closed, inhibiting the practice of physical exercise in this period. The data above indicate that the COVID-19 pandemic worsened the situation of Iow MVPA activity for $68.3 \%$ of MS since the observed values are higher than those verified in previous studies with MS in Thailand of $49.5 \%^{13}$ and the United States of $22.0 \% .^{14}$

Finally, we highlight three points that together show the worst situation for MS during the COVID-19 pandemic. First, regarding anxiety symptoms, depression symptoms, and quality of sleep, more than half the sample $(50.5 \%, 50.5 \%$, and $66.2 \%$, respectively) presented values classified as high anxiety and depression symptoms and poor sleep quality. These values are higher than other studies performed in periods outside the pandemic. ${ }^{18}$ Second, the majority of MS considered that the pandemic had altered their level of physical activity and SB (83.5\%), anxiety symptoms (82.2\%), and depression symptoms (54.6\%). Third, approximately $10 \%$ of the sample had been diagnosed with COVID-19.

Our study has limitations. The cross-sectional design and the absence of outcomes of MS in periods outside the COVID-19 pandemic (repeated measures) are limitations. In addition, comparing MS with other groups of students from other health courses is essential for understanding whether other students (e.g., Physiotherapy or Physical Education) demonstrate a similar impact of the COVID-19 pandemic on 
MVPA, anxiety symptoms, and depression symptoms. The lack of a sample of MS from a different University is also a limitation. Physical activity and sleep quality assessments carried out by questionnaires are a limitation, mainly due to the subjectivity of the measure. Including MS who were diagnosed with COVID-19 can also be considered a limitation, despite the percentage being $10 \%$ of the sample.

\section{CONCLUSION}

We concluded that MS who perform more minutes MVPA a week (Median=390 minutes) present a lower presence of anxiety symptoms and depression symptoms than MS who perform lower minutes MVPA a week (Median=0 minute).

\section{ACKNOWLEDGEMENTS}

To the class representatives and the medical students involved in the research. FAPESP (Grants 2020/08869-0 and 2021/06268-1), CNPq (PIBIC CNPq) and the other funding bodies mentioned.

All authors declare no potential conflict of interest related to this article

AUTHORS' CONTRIBUTIONS: Each author made significant individual contributions to this manuscript. TBM: Conceptualization, methodology, formal analysis, investigation, writing - original draft, writing - review \& editing, visualization. KCS: Conceptualization, methodology, formal analysis, investigation, writing - original draft, writing - review \& editing, visualization. CNF: Conceptualization, methodology, writing - original draft, writing - review \& editing. FER:Writing - review \& editing. RPGS:Writing - review \& editing. KD:Writing - review \& editing. IT:Writing - review \& editing. JEA: Conceptualization, methodology, writing - review \& editing. BS: Writing - review \& editing. LMN: Conceptualization, methodology, formal analysis, writing - original draft, writing - review, supervision.

\section{REFERENCES}

1. Guan W-J, Ni Z-Y, Hu Y, Liang W-H, Ou C-Q, He J-X, et al. Clinical characteristics of coronavirus disease 2019 in China. J Emerg Med. 2020;58(4):711-2.

2. Sachs JD, Karim SA, Aknin L, Allen J, Brosbøl K, Barron GC, et al. Lancet COVID-19 Commission Statement on the occasion of the 75th session of the UN General Assembly. Lancet. 2020;396(10257):1102-24.

3. UNESCO. Education: From disruption to recovery: UNESCO; 2020 [cited 2020 14/12/2020]. Available from: https://en.unesco.org/covid19/educationresponse.

4. Meyer J, Herring M, McDowell C, Lansing J, Brower C, Schuch F, et al. Joint prevalence of physical activity and sitting time during COVID-19 among US adults in April 2020. Prev Med Rep. 2020;20:101256.

5. Schuch FB, Bulzing RA, Meyer J, Vancampfort D, Firth J, Stubbs B, et al. Associations of moderate to vigorous physical activity and sedentary behavior with depressive and anxiety symptoms in self-isolating people during the COVID-19 pandemic: A cross-sectional survey in Brazil. Psychiatry Res. 2020;292:113339.

6. Galea S, Merchant RM, Lurie N. The Mental Health Consequences of COVID-19 and Physical Distancing: The Need for Prevention and Early Intervention. JAMA Intern Med. 2020;180(6):817-8.

7. Jacob L, Tully MA, Barnett Y, Lopez-Sanchez GF, Butler L, Schuch F, et al. The relationship between physical activity and mental health in a sample of the UK public: A cross-sectional study during the implementation of COVID-19 social distancing measures. Ment Health Phys Act. 2020;19:100345.

8. Firth J, Solmi M, Wootton RE, Vancampfort D, Schuch FB, Hoare E, et al. A meta-review of "lifestyle psychiatry": the role of exercise, smoking, diet and sleep in the prevention and treatment of mental disorders. World Psychiatry. 2020;19(3):360-80.

9. Vancampfort D, Rosenbaum S, Schuch F, Ward P, Richards J, Mugisha J, et al. Cardiorespiratory Fitness in Severe Mental IIIness: A Systematic Review and Meta-analysis. Sports Med. 2017;47(2):343-52.

10. Vancampfort D, Firth J, Schuch FB, Rosenbaum S, Mugisha J, Hallgren M, et al. Sedentary behavior and physical activity levels in people with schizophrenia, bipolar disorder and major depressive disorder: a global systematic review and meta-analysis. World Psychiatry. 2017;16(3):308-15.

11. Schuch FB, Stubbs B, Meyer J, Heissel A, Zech P, Vancampfort D, et al. Physical activity protects from incident anxiety: A meta-analysis of prospective cohort studies. Depress Anxiety. 2019;36(9):846-58.

12. Baumeister SE, Leitzmann MF, Bahls M, Dörr M, Schmid D, Schomerus G, et al. Associations of leisure-time and occupational physical activity and cardiorespiratory fitness with incident and recurrent major depressive disorder, depressive symptoms, and incident anxiety in a general population. J Clin Psychiatry. 2017;78(1):e41-7.

13. Wattanapisit A, Fungthongcharoen K, Saengow U, Vijitpongjinda S. Physical activity among medical students in Southern Thailand: a mixed methods study. BMJ open. 2016;6(9): e013479.

14. Stanford FC, Durkin MW, Stallworth JR, Blair SN. Comparison of physical activity levels in physicians and medical students with the general adult population of the United States. Phys Sportsmed. 2013;41(4):86-92.

15.Zeng W, Chen R, Wang X, Zhang Q, Deng W. Prevalence of mental health problems among medical students in China: A meta-analysis. Medicine (Baltimore). 2019;98(18):e15337.

16. Mao Y, Zhang N, Liu J, Zhu B, He R, Wang X. A systematic review of depression and anxiety in medical students in China. BMC Med Educ. 2019;19(1):327.

17. Pacheco JP, Giacomin HT, Tam WW, Ribeiro TB, Arab C, Bezerra IM, et al. Mental health problems among medical students in Brazil: a systematic review and meta-analysis. Rev Bras Psiquiatr. 2017;39(4):369-78.
18. Rotenstein LS, Ramos MA, Torre M, Segal JB, Peluso MJ, Guille C, et al. Prevalence of Depression, Depressive Symptoms, and Suicidal Ideation Among Medical Students: A Systematic Review and Meta-Analysis. Jama. 2016;316(21):2214-36.

19. Goodyear MD, Krleza-Jeric K, Lemmens T. The declaration of Helsinki. London: British Medical Journal Publishing Group; 2007.

20. SPSG. Sao Paulo's State Government - Sao Paulo plan 2020 [cited 2021 03/01/2020]. Available from: https://www.saopaulo.sp.gov.br/planosp/.

21. Sergeant E. Epitools epidemiological calculators. AusVet Animal Health Services and Australian Biosecurity Cooperative Research Centre for Emerging Infectious Disease. 2009.

22. Craig CL, Marshall AL, Sjöström M, Bauman AE, Booth ML, Ainsworth BE, et al. International physical activity questionnaire: 12-country reliability and validity. Med Sci Sports Exerc. 2003;35(8):1381-95.

23. Matsudo S, Araújo T, Marsudo V, Andrade D, Andrade E, Braggion G. Questinário internacional de atividade f1sica (IPAQ): estudo de validade e reprodutibilidade no Brasil. Rev bras ativ fís saúde. 2001;6(2):5-18.

24. Beck AT, Epstein N, Brown G, Steer RA. An inventory for measuring clinical anxiety: psychometric properties. J Consult Clin Psychol. 1988;56(6):893-7.

25. Beck AT, Steer RA. Beck Anxiety Inventory: BAI. San Antonio, TX:Psychological Corporation; 1993.

26. Bardhoshi G, Duncan K, Erford BT. Psychometric meta-analysis of the English version of the Beck Anxiety Inventory. J Couns Dev J Couns Dev. 2016;94(3):356-73.

27. Cunha JA. Manual da versão em português das Escalas Beck. São Paulo: Casa do psicólogo; 2001

28. Sæmundsson BR, Pórsdóttir F, Kristjánsdóttir H, Ólason DP, Smári J, Sigurðsson JF. Psychometric properties of the Icelandic version of the Beck Anxiety Inventory in a clinical and a student population. Eur J Psychol Assess. 2011;27(2):133-41.

29. Gomes-Oliveira MH, Gorenstein C, Lotufo Neto F, Andrade LH, Wang YP. Validation of the Brazilian Portuguese version of the Beck Depression Inventory-ll in a community sample. Braz J Psychiatry. 2012;34(4):389-94.

30. Gorenstein C, Pang W, Argimon I, Werlang B. Manual do Inventário de depressão de Beck-BDI-II. São Paulo: Editora Casa do Psicólogo; 2011.

31. Shean G, Baldwin G. Sensitivity and specificity of depression questionnaires in a college-age sample. Genet Psychol. 2008;169(3):281-8.

32. Buysse DJ, Reynolds III CF, MonkTH, Berman SR, Kupfer DJ. The Pittsburgh Sleep Quality Index: a new instrument for psychiatric practice and research. Psychiatry Res. 1989;28(2):193-213.

33. Bertolazi AN, Fagondes SC, Hoff LS, Dartora EG, da Silva Miozzo IC, de Barba MEF, et al. Validation of the Brazilian Portuguese version of the Pittsburgh sleep quality index. Sleep Med. 2011;12(1):70-5.

34. Rao W-W, Li W, Qi H, Hong L, Chen C, Li C-Y, et al. Sleep quality in medical students: a comprehensive meta-analysis of observational studies. Sleep Breath. 2020;24(3):1151-65.

35. Rajab MH, Gazal AM, Alkattan K. Challenges to Online Medical Education During the COVID-19 Pandemic. Cureus. 2020;12(7):e8966.

36. Luciano F, Cenacchi V, Vegro V, Pavei G. COVID-19 lockdown: physical activity, sedentary behaviour and sleep in Italian medicine students. Eur J Sport Sci. 2020;1-10. 